\title{
Organizational Commitment and Perceived Organizational Performance Among Health Care Professionals: Empirical Evidence From A Private Hospital in Northern Cyprus
}

\author{
*Aysen Berberoglu, Hikmet Secim \\ Cyprus International University, North Cyprus \\ *aysenb@ciu.edu.tr
}

\begin{abstract}
Organizational commitment plays an important role in employee behavior. It is related with self identification of the employee with his/her organization. Self-identified employee, with higher scores of commitment, is expected to be more motivated, retaining at the organization and performing at significant levels of performance. Perceived organizational performance, on the other hand, is concerned with how employees are observing their organizations in terms of success, sustainability and development. The aim of this study was to assess the hypothesized relationship between organizational commitment and perceived organizational performance among health care professionals, by taking a small-sized private hospital in North Cyprus as the setting. The study was conducted by utilizing structured, self-administered questionnaires and collected data was analyzed by using SPSS. Study revealed that in this case, there is a positive significant relationship between organizational commitment and perceived organizational performance and organizational commitment is affecting the perceived organizational performance of the health care workers.
\end{abstract}

Keywords: Organizational commitment, health care, perceived organizational performance, private hospital, employee behavior

\section{Introduction}

In health care organizations, employee attitudes in terms of motivation, commitment and satisfaction can be considered more important when compared to other sectors, considering that the health care service is directly provided by health workers to the patients. Having highly committed employees within health care institutions plays an important role in improving the overall performance of the services provided leading to patient satisfaction. Many studies in the literature were conducted in order to measure these attitudes within organizational settings like organizational commitment, job satisfaction, turnover intentions, motivation and performance (Porter et al., 1974; Knoop, 1995; Lum, 1998; Al-aameri, 2000; McNeese-Smith \& Nazarey, 2001; Çayköylü et al., 2011; Altındiş, 2011). On the other hand, levels of organizational commitment is found to be affecting employees' perceptions regarding how they observe the overall performance of their organizations, namely the perceived organizational performance (Camilleri \& Van Der Heijden, 2007). According to literature, rather than using the secondary data (like annual performance evaluation results) a subjective measurement of organizational performance can be made by observing the perceptions of employees regarding performance of their organizations by a comparison with competitors in the same industry (Tzafrir, 2006).

There are many studies in the literature which used measurement of perceived organizational performance and concluded that there is a relationship between organizational commitment and perceived organizational performance, even though in some cases a mediator variable was also present (Bakiev, 2013; Camilleri \& Van Der Heijden, 2007; Mansour, Gara \& Gaha, 2013). The aim of the present study is to reveal the nature of hypothesized relationship between organizational commitment and perceived organizational performance in a privately owned, small sized health care setting in Northern Cyprus regarding the health care professionals. The present study is the first study that was carried out regarding the hypothesized relationship between organizational commitment and perceived organizational performance of health care professionals in Northern Cyprus. It was also a part of a nation wide study, later than expanded to all health care workers currently working in public hospitals in TRNC.

\section{Literature Review}

Organizational Commitment and Organizational Performance: Organizational commitment is an important concept in terms of employee loyalty and efficiency for an organization. For the first time in the 
literature, the concept of commitment was defined by Becker in 1960 "one mechanism producing consistent human behaviour" (Becker, 1960). Later in 1974, Porter et al. (1974) explained the concept of organizational commitment as the collective attitude of employees toward their organizations and additionally defined organizational commitment as "the strength of an individual's identification with and involvement in a particular organization". Organizational commitment is also stated as a psychological state that forms the relationship of employee's with the organization and decision to retain at the organization or leave (Meyer \& Allen, 1991). Highly committed employees easily embrace their organization's goals and values; have a willingness to put effort for the well being of the organization; and an unlimited desire to stay at the current organization (Porter, Steers and Boulian, 1974). According to Angle and Perry (1981), it is possible to assume that organizations with strongly committed employees would have effectiveness in terms of high participation and high production leading to relatively low levels of absenteeism and turnover resulting in high levels of operating performance.

Employee performance can be defined as the measurement of how well or poorly an employee has accomplished a task given and it is possible to assume that motivation, personality and ability are influencing employee's performance. (George and Jones, 2012). Continously, sum of all employees performance in the organization creates the overall organizational performance therefore an improvement in organizational performance can be achieved only through the employees' individual performances (Mullins, 2010). In order to measure organizational performance a mixture of the level of perceived organizational effectiveness, employee's morale and turnover intentions are commonly taken as the criteria (Jain, 2012). Perceived organizational performance can be defined as the employee perceptions regarding their organization's overall performance and perceived organizational performance is related with human resources management practices that directly affects the employees' attitudes within an organization (Allen and Helms, 2002 cited in Mullins, 2010). According to Giauque et al. (2013), consequently human resources practices in an organization contributes to organizational performance and organizational performance can be defined as the individual perception of organizational efficiency by employees. Organization's human resource practices should concern about employees attitudes and beliefs, because false beliefs may lead them to perform not at their best and their motivation and performance may suffer which cause lower organizational performance (George and Jones, 2012).

Since the beginning of 2000s the relationship between organizational commitment and perceived organizational performance has gained significant attention in the organizational behaviour literature. Several studies in the literature concluded that there is a relationship between organizational commitment of the employees and their perceptions about organizational perfrormance. A recent study carried out in 2013 by Bakiev suggested that high performance work systems mediated the relationship between organizational commitment and perceived organizational performance and even in the absence of high performance work systems organizations should encourage their employees' organizational commitment which will influence organizational performance positively. Another study conducted by Bakiev (2013) investigated the hyptothesized influence of organizational commitment on perceived organizational performance among police officers in Krygyzistan and findings revealed that organizational commitment has a positive influence on perceived organizational performance. Continously, Mansour et al. (2013) has concluded that organizational commitment was positively related to perceived organizational performance as a result of their study regarding HRM practices and firm performance in Tunisian financial services industry. One of the previous research performed in public sector which aimed to link organization commitment and organizational performance and results showed that there is a positive relationship between informal performance level (which is the organizational performance level perceived by employees) and organizational commitment (Camilleri and Van Der Heijden, 2007). However there is no certain agreement in the literature on the positive relationship between the two concepts because some studies have contrary findings. For instance, Biçer et al's study (2009) regarding affective organizational commitment and perceived organizational performance did not conclude a statistically significant relationship between the two concepts.

\section{Methodology}

The research was carried out during September 2014 as the preliminary study of a country wide study, which later was extended to the health care workers currently working in all public hospitals of TRNC. The study has taken a small sized private hospital as the case, and aimed to reach the maximum possible number of respondents. The data was collected with the help of self-administered questionnaires. Fifty 
questionnaires were distributed and thirty-eight usable questionnaires were collected back. The research only utilized primary data collected from the health care workers. Perceived organizational performance was evaluated only according to the perceptions of the respondents, secondary data about performance evaluations of the hospital were not involved in the analysis. There was no control group among the respondents.

Hypothesis: The hypothesis which was adopted by the study, as a result of literature review, are as follows:

$\mathrm{H}_{1}$ : There is a significant positive relationship between organizational commitment and perceived organizational performance.

$\mathrm{H}_{2}$ : Organizational commitment is influencing perceived organizational performance

Sample: The aim of the research was to carry out a study regarding the relationship between organizational commitment and perceived organizational performance among health care professionals working in private health institutions. Currently there are eight private hospitals in Northern Cyprus. The sample of the study consisted the health care workers currently working in one of these eight private and small-sized hospitals. Classification of the hospitals can be made according to their bed capacities (as 25, 50, 100, 200, 400, 600, 800 and above) (Seçim,1994). The sample private hospital has 13 beds capacity, that can be considered as a small-sized hospital. The sample of the study included managers, doctors/practitioners, nurses and chemists. In this hospital, 50 questionnaires were distributed and 38 usable questionnaires were collected back.

Instrumentation: The study was carried out by distributing structured and self-administrated questionnaires to the respondents. Survey questions included demographic data as well as information regarding level of organizational commitment and perceived organizational performance of the employees. Questions from Allen and Meyer's (1991) organizational commitment questionnaire was adopted in order to measure the level of organizational commitment of the health care employees. On the other hand questions from Delaney and Huselid's (1996) study regarding the perceived organizational performance was used. A 5-point Likert Scale was used to measure the organizational commitment and perceived organizational performance of the employees ranging from 1- Strongly Agree to 5- Strongly Disagree. The questionnaire was translated and distributed in Turkish language, in order to get the most exact answers from the respondents. Reliability analysis were utilized in order to test the reliability of the used instrument. The results revealed that both organizational commitment items and perceived organizational climate items of the instrument have satisfying Cronbach's alpha values, 0,853 and 0,797 respectively (Please refer to Appendix). By taking the small sample size into consideration, factor analysis was not carried out.

\section{Results and Discussion}

Frequencies: In the first section of the questionnaire, respondents were introduced with questions regarding their demographic data and data related with their work. Table 1 İnvolves results of the data collected in the first section.

Table 1: Frequencies

\begin{tabular}{lll}
\hline Variable & Frequency & Percentage (\%) \\
\hline Gender & 29 & 76,3 \\
$\quad$ Female & 8 & 21,1 \\
$\quad$ Male & & \\
Age & 16 & 42,1 \\
Between 20-30 & 12 & 31,6 \\
Between 31-40 & 9 & 23,7 \\
Between 41-50 & 0 & 0 \\
More than 50 & &
\end{tabular}


Marital Status

\begin{tabular}{lll}
\hline Variable & Frequency & Percentage (\%) \\
\hline Married & 30 & 78,9 \\
Single & 7 & 18,4 \\
Widowed & 0 & 0 \\
Duty & & \\
Manager & 2 & 5,3 \\
Doctor / Practitioner & 4 & 10,5 \\
Nurse & 21 & 55,3 \\
Other & 11 & 28,9 \\
Salary & & \\
$€ 465-645$ & 24 & 63,2 \\
$€ 660-1000$ & 7 & 18,4 \\
More than $€ 1000$ & 7 & 18,4 \\
\hline
\end{tabular}

According to the results of demographic data, majority of the respondents were female health workers (76.3\%). The age distribution of the respondents is relatively young there are no employees with age more than 50 and the majority is between 20-30 years (42.1\%). Continously, majority of the health care worker respondents are found to be married (78.9\%). As a part of the questionnaire, respondents were asked about their duties at their hospital. Majority of the respondents are found to be nurses (55.3\%), a few were at the management level (5.3\%) and some of them were doctors/practitioners $(10.5 \%)$. Additionally, $28.9 \%$ of the respondents involved chemists, laboratory assistants, sick nurses and clerical health workers. Lastly, health care workers were questioned about their monthly salaries. Majority of the respondents answered as they are receiving a monthly salary approximately between €465-€645 per month.

Analysis of Hypothesis: Analysis of variance test was conducted in order to reveal the hypothesized relationship between organizational commitment of the employees and their perceived organizational performance. According to the results of the analysis, there is a statistically significant relationship $(0.034<0.05)$ between organizational commitment and perceived organizational performance of the employees (relationship is significant at 0.05 level).

Table 2: ANOVA Test

\begin{tabular}{llllll}
\hline $\begin{array}{l}\text { Organizational Commitment ANOVA } \\
\text { Perceived organizational performance } \\
\end{array}$ & Sum of Squares & df & Mean Square & F & Sig. \\
\hline Between Groups & 9,910 & 19 &, 522 & 4,012 &, 034 \\
Within Groups &, 910 & 7 &, 130 & & \\
Total & 10,821 & 26 & & & \\
\hline
\end{tabular}

Continously, correlation analysis has been performed aiming to indicate what kind of relationship (positive or negative) is present between organizational commitment and perceived organizational performance in this case.

According to the results of the correlations, there is a positive relationship between organizational commitment and perceived organizational performance. Positive results pointed out that as the level of organizational commitment increases, the level of perceived organizational performance also increseas and as the level of organizational commitment decreases, the level of perceived organizational 
performance also decreases also vice versa. Additionally, Pearson Correlation test demostrated that the present positive relationship is a strong relationship, with $\mathrm{R}=0.785$, between the two concepts.

Table 3: Correlations Test

\begin{tabular}{llll}
\hline Correlations & & & \\
& & commitment & performance \\
\hline commitment & Pearson Correlation & 1 &, $785^{* *}$ \\
& Sig. (2-tailed) & &, 000 \\
performance & $\mathrm{N}$ & 32 & 27 \\
& Pearson Correlation &, $785^{* *}$ & 1 \\
& Sig. (2-tailed) &, 000 & \\
& $\mathrm{~N}$ & 27 & 32 \\
\hline
\end{tabular}

**. Correlation is significant at the 0.01 level (2-tailed).

Additionally, in order to understand the nature of the relationship between organizational commitment and perceived organizational performance in detail, Simple Linear Regression test was applied to the collected data. Organizational commitment is considered as the independent variable and perceived organizational performance was assumed as the dependent variable, as stated in hypothesis.

Table 4: Model Summary

\begin{tabular}{|c|c|c|c|c|}
\hline \multicolumn{5}{|c|}{ Model Summary } \\
\hline Model & $\mathbf{R}$ & R Square & Adjusted R Square & Std. Error of the Estimate \\
\hline 1 & ,785a & ,616 & 601 & ,40771 \\
\hline
\end{tabular}

a. Predictors: (Constant), organizational commitment

According to the result of $\mathrm{R}$ square, it is possible to comment that $60 \%$ of the perceived organizational performance of health care employees is affected by their organizational commitment $(\mathrm{R}=0.601)$.

Table 5: ANOVA Test

\begin{tabular}{|c|c|c|c|c|c|c|}
\hline \multicolumn{7}{|c|}{ ANOVA $^{b}$} \\
\hline Model & & Sum of Squares & df & Mean Square & $\mathbf{F}$ & Sig. \\
\hline \multirow[t]{3}{*}{1} & Regression & 6,665 & 1 & 6,665 & 40,095 & ,000a \\
\hline & Residual & 4,156 & 25 & ,166 & & \\
\hline & Total & 10,821 & 26 & & & \\
\hline
\end{tabular}

a. Predictors: (Constant), organizational commitment

b. Dependent Variable: perceived organizational performance

One way ANOVA test also supported the hypothesis by revealing that there is a statistically meaningful relationship between the dependent and independent variable (sig. $=0.000$ ). Also, coefficients table of the regression supported the positive significant relationship of the two concepts.

\section{Table 6: Coefficients}

\begin{tabular}{|c|c|c|c|c|c|c|}
\hline \multicolumn{7}{|c|}{ Coefficients $^{a}$} \\
\hline \multirow{2}{*}{\multicolumn{2}{|c|}{ Model }} & \multicolumn{2}{|c|}{ Unstandardized Coefficients } & \multicolumn{3}{|c|}{ Standardized Coefficients } \\
\hline & & B & Std. Error & Beta & $\mathbf{t}$ & Sig. \\
\hline \multirow[t]{2}{*}{1} & (Constant) & 1,667 & ,365 & & 4,562 & 000 \\
\hline & $\begin{array}{l}\text { Organizational } \\
\text { commitment }\end{array}$ & 665 & ,105 & ,785 & 6,332 & ,000 \\
\hline
\end{tabular}

a. Dependent Variable: perceived organizational performance 
The results of the analysis have supported the hypothesis of the study and revealed that, there is a positive significant relationship between organizational commitment and perceived organizational performance. Also it is possible to comment that organizational commitment is affecting the perceived organizational performance of the health care workers.

\section{Conclusion and Recommendations}

The results of the present study were in line with the existing findings in the literature, like Bakiev's (2013) who also concluded that the level of organizational commitment is affecting the perceived organizational performance of the health care workers. According to the results of the statistical analysis, it is possible to conclude that there is a statistically significant relationship between level of organizational commitment and perceived organizational performance of the health care workers. The relationship between the two concepts represents a positive relationship indicating that as the level of organizational commitment increases, the perceived organizational performance will increase as well. Continously, perceived organizational performance of the employees is influenced by their level of organizational commitment. It is possible to interpret that, besides having an influence on the overall organizational performance, level of organizational commitment is also affecting how the employees are observing the performance of their organizations.

The study was carried out in a privately owned, small sized hospital in Northern Cyprus, so the findings of the study can not be generalized to all private health care settings in the same area. The study can be repeated by collecting more data from all private and also public health care centers and hospitals in order to generalize the results to all hospitals in Northern Cyprus. A wide range of respondents should be surveyed in order to understand the nature of the relationship more clearly. Also, other concepts related with antecedents and consequences (organizational culture, job satisfaction, motivation and motivation) of the organizational commitment can be added to the study in order to reveal whether the relationship between organizational commitment and perceived organizational performance is moderated or mediated by other variables. Continously, further studies can be designed considering whether having a positive perceived organizational performance would influence other factors like satisfaction or motivation of the health care workers in a positive way. Lastly, the present study aimed to measure the expected influence of the organizational commitment on perceived performance, however it is also possible to hypothesize the reverse influence in the future studies. That is; the expected influence of perceived organizational performance on organizational commitment. A new research question can be proposed as; "would perceiving high levels of organizational performance affect the organizational commitment of the employees positively?."

\section{References}

Al-Aameri, A. S. (2000). Job satisfaction and organizational commitment for nurses. Saudi Medical Journal, 21(6), 531-535.

Altındiş, S. (2011). Job motivation and organizational commitment among the health professionals: A questionnaire survey. African Journal of Business Management, 5, 8601-8609

Angle, H. L. \& Perry, J. L. (1981). An Empirical Assessment of Organizational Commitment and Organizational Effectiveness. Administrative Science Quarterly, 26(1), 1-14.

Bakiev, E. (2013). The Influence of Interpersonal Trust and Organizational Commitment on Perceived Organizational Performance. Journal of Applied Economics and Business Research JAEBR, 3(3), 166-180

Becker, H. S. (1960). Notes on the concept of commitment. American Journal of Sociology, 66, 32-42

Biçer, İ. H., Erçek, M., Küskü, F. \& Çakmak, A. F. (2009). Örgütsel bağlılığın duygusal bileşenleri: Türk kamu kuruluşunda kapsamlı bir yapısal denklem modeli. İstanbul Teknik University Journal, 8(4).

Camilleri, E. \& Van der Heijden, B. I. J. M. (2007). Organizational commitment, public service motivation, and performance within the Public Sector. Public Performance \& Management Review, 31(2), 241-274.

Çayköylü, S., Egri, C. P., Havlovic, S. \& Bradley, C. (2011). Key organizational commitment antecedents for nurses, paramedical professionals and non-clinical staff. Journal of Health Organization Management, 25, 7-33

Delaney, J. T. \& Huselid, M. A. (1996). The Impact of Human Resource Management Practices on Perceptions of Organizational Performance. Academy of Management Journal, 39, 949-969. 
George, J. M. \& Jones, G. R. (2012). Understanding and Managing Organizational Behavior sixth ed. Prentice Hall New Jersey

Giauque, D., Anderfuhren-Biget, S. \& Varone, F. (2013). HRM Practices, Intrinsic Organizational Performance in the Public Sector. Public Personnel Management, 42(2), 123-150

Jain, A. K. (2012). Impact of Organizational Size \& Alliance Formations on Perceived Organizational Performance. The Indian Journal of Industrial Relations, 47(3).

Knoop, R. (1995). Relationships among job involvement, job satisfaction, and organizational commitment for nurses. The Journal of Psychology, 129(6), 643-649

Lum, L. (1998). Explaining nursing turnover intent: job satisfaction, pay satisfaction, or organizational commitment? Journal of Organizational Behavior, 19, 305-21

Mansour, N., Gara, E. \& Gaha, C. (2013). Getting inside the black box: HR practices and firm performance within the Tunisian financial services industry. Personnel Review, 43(4), 490-514

McNeese-Smith, D. K. \& Nazarey, M. (2001). A nursing shortage: building Organizational commitment among nurses / practitioner application. Journal of Health Care Management, 46, 173-187

Meyer, J. P. \& Allen, N. J. (1991). A Three Component Conceptualization of Organizational Commitment. Human Resource Management Review, 1, 61-89

Mullins, L. (2010). Management and Organizational Behavior Ninth. Ed. Pearson Education Essex England Porter, L. W., Steers, R. M. \& Boulian, P. V. (1974). Organizational Commitment, Job Satisfaction and Turnover Among Psychiatric Technicians. Journal of Applied Psychology, 59, 603-609

Seçim, H. (1994). Hastane Yönetimi ve Organizasyonu. Eskişehir: Anadolu University Publishings, 845, 2.

Tzafrir, S. S. (2006). A universalistic perspective for explaining the relationship between HRM practices and firm performance at different points in time. Journal of Managerial Psychology, 21(2), 109 130

\section{APPENDIX}

\begin{tabular}{|c|c|c|c|c|}
\hline \multicolumn{2}{|c|}{ Reliability Statistics } & & & \\
\hline Cronbach's Alpha & $\mathrm{N}$ of Items & & & \\
\hline 0.853 & 18 & & & \\
\hline \multicolumn{5}{|c|}{ Item-Total Statistics } \\
\hline & $\begin{array}{l}\text { Scale Mean if Item } \\
\text { Deleted }\end{array}$ & $\begin{array}{l}\text { Scale Variance } \\
\text { Item Deleted }\end{array}$ & $\begin{array}{c}\text { if Corrected Item- } \\
\text { Total Correlation }\end{array}$ & $\begin{array}{l}\text { Cronbach's Alpha if } \\
\text { Item Deleted }\end{array}$ \\
\hline Commitment & 58,4375 & 142,190 & ,676 & ,836 \\
\hline Commitment & 58,1875 & 138,609 & ,805 & ,831 \\
\hline Commitment & 58,1562 & 140,072 & 777 & ,832 \\
\hline Commitment & 58,3438 & 155,910 & ,235 & ,854 \\
\hline Commitment & 58,6250 & 141,984 & ,623 & 838 \\
\hline Commitment & 58,5625 & 148,254 & 386 & ,849 \\
\hline Commitment & 59,1250 & 137,532 & 697 & ,833 \\
\hline Commitment & 58,5938 & 148,120 & ,428 & ,847 \\
\hline Commitment & 59,2500 & 150,065 & ,340 & ,851 \\
\hline Commitment & 58,6250 & 141,210 & ,664 & ,836 \\
\hline Commitment & 58,5938 & 138,572 & ,773 & 831 \\
\hline Commitment & 58,4062 & 142,443 & ,705 & ,836 \\
\hline Commitment & 58,3438 & 135,007 & ,823 & ,828 \\
\hline \multirow[t]{2}{*}{ Commitment } & 58,4062 & 136,894 & ,769 & ,831 \\
\hline & $\begin{array}{l}\text { Scale Mean if Item } \\
\text { Deleted }\end{array}$ & $\begin{array}{l}\text { Scale Variance } \\
\text { Item Deleted }\end{array}$ & $\begin{array}{c}\text { if Corrected Item- } \\
\text { Total Correlation }\end{array}$ & $\begin{array}{l}\text { Cronbach's Alpha if } \\
\text { Item Deleted }\end{array}$ \\
\hline Commitment & 58,8438 & 165,814 &,- 125 & ,873 \\
\hline Commitment & 58,6875 & 156,867 & ,111 & ,863 \\
\hline Commitment & 58,5938 & 164,378 &,- 087 & ,871 \\
\hline Commitment & 58,7500 & 159,935 & ,034 & ,865 \\
\hline
\end{tabular}


Reliability Statistics

\begin{tabular}{ll}
\hline Cronbach's Alpha & N of Items \\
\hline 0.797 & 8 \\
\hline
\end{tabular}

Item-Total Statistics

\begin{tabular}{lllll}
\hline & $\begin{array}{l}\text { Scale Mean if Item Scale Variance } \\
\text { Deleted }\end{array}$ & $\begin{array}{c}\text { if Corrected } \\
\text { Item Deleted }\end{array}$ & $\begin{array}{c}\text { Item- Cronbach's Alpha if } \\
\text { Total Correlation } \\
\text { Item Deleted }\end{array}$ \\
\hline Performance & 27,1875 & 21,512 &, 544 &, 772 \\
Performance & 27,1562 & 20,975 &, 608 &, 763 \\
Performance & 27,5625 & 20,964 &, 486 &, 778 \\
Performance & 27,9375 & 18,383 &, 529 &, 776 \\
Performance & 26,8125 & 21,964 &, 603 &, 770 \\
Performance & 27,6562 & 18,039 &, 628 &, 754 \\
Performance & 27,4062 & 21,152 &, 373 &, 798 \\
Performance & 27,0312 & 22,096 &, 435 &, 785 \\
\hline
\end{tabular}

